\title{
Editorial
}

\section{Brand equity: Both ends of the spectrum}

Brand equity, like almost every other term and concept used in marketing and communication, has been borrowed from something or somewhere else. Originally, equity meant equal or fair. Later, it moved into the legal system. There it meant the supplementary rules and doctrines that aid in the levelling of common and statute law. Somehow, equity then leapt the fence into economics. There it has come to mean an owner's share or value of a property or asset above any liens or charges against it.

And now we have 'borrowed' equity for marketing and branding. So, given the chequered background of the term, it is no wonder marketers have so much trouble coming to grips with what 'equity' is and how it might be increased, enhanced, extended and, yes, even measured.

Brand equity, in marketing terms, has a number of meanings. To help untangle the conundrum, we have gathered some of the world's best marketing, communication and branding experts and let them have a go at brand equity. And, as you will see, they provide a broad view of what brand equity is, what it means, how it can be valued and how it can be measured.

One of the challenges of defining and determining brand equity is what the measurement yardstick will be. Historically, marketing and communication measures have been based on psychological models, and thus on psychological measures. For the last 60 or so years, attitudinal measures such as awareness, recognition and intent to buy have all been used to determine the impact and effects of marketing and communication programmes. This, naturally, has spread to brand and brand equity measures. Thus, brand equity for many marketers has been defined through consumer attitudes, meanings, values, concepts and so on. The premise is that attitudinal change or reinforcement will lead to purchasing behaviour.

Alternatively, over the last few years another view of brand equity has arisen. Coming from accounting and finance, the effort has been to place a financial value on what is essentially an intangible asset. Thus, brand equity is the financial value of the brand in terms of ownership or the ongoing income flows the brand might and could generate for the owner.

So, two views. Two alternative measures. And a gulf between them almost as wide as the dictionary definitions used to start this editorial.

One way to think about brand equity is as a continuum. At one end is the psychological value of the brand; that is, the value the customer or consumer or society places on the brand which, it is believed, will generate ongoing and perhaps increasing customer relationships for the brand now and into the future. At the other end is the present and future financial value of the brand. That is the amount the brand is worth to the owner either as an intangible asset that could be sold or as an income-producing asset that can and will generate future value.

Brand value, and therefore brand equity, occurs all along this continuum. It is the managerial need that defines how the measure will be taken and the way brand equity will be viewed. At one end, one might measure the brand's financial value, ignoring the customers who create that value. At the other end, the firm might have considerable customer knowledge and insight, but little capacity to relate that to the financial operations of the firm. So, going back to the Greek use of the term, brand equity really does need to be thought of as equal or fair - equal or fair in terms of how the measure of brand value is being made and how it will be used by the brand owner and manager.

The problem, of course, is that different measurement tools are used at either end of the spectrum. At the consumer brand equity end, attitudinal measures are used. At the financial end, monetary values are used. So, the challenge of brand equity and brand equity measurement has been the combining of attitudes and behaviours or, better said, feelings versus dollars. 


\section{Editorial}

In this special issue, we run through the spectrum of views on brand equity and brand equity measurement. Kevin Lane Keller, a professor in Tuck School at Dartmouth University in the USA, starts the issue off with his view of consumer brand equity - that is, the value consumers or customers place on the brand. At the other end of the spectrum, David Haigh, MD of Brand Finance, presents the case for financial brand equity.

In between, Michael Leiser of Prophet, the brand consultancy firm, suggests ways brand equity can be financially valued using consumer brand equity views. More towards the financial view, Jonathan Knowles offers the new combination of a financial measure, Economic Value Added, connected to the long-running BrandAsset ${ }^{\mathbb{R}}$ Valuator developed by the advertising firm Young \& Rubicam. Both make strong arguments for their approaches.

And sitting squarely in the middle is a best practice paper concerning an internationally known firm, Boeing, which has been aggressively trying to find a way to determine the equity of its brand in all the maze of alternatives. Anne Toulouse and Carrie Howard provide an interesting insight into the trip Boeing has made on the way to brand equity determination and measures.

The answer, of course, is up to you. The five views represent what we believe is the spectrum of brand equity measures. Granted, there are other methodologies, but all are trying to get at the same answer. What is brand equity and how can it be measured?

So, in the true sense of marketing, let us borrow from literature and paraphrase the author Lewis Carroll, who wrote: 'It's [brand equity] exactly what I say it is. Nothing more and nothing less.' That seems to sum up brand equity today, and particularly brand equity measurement.

Professor Don E. Schultz Northwestern University, USA Guest Editor, Special Issue on Brand Equity 